\title{
Microbial Treatment of Tannery Effluent by Augmenting Psychrotrophic Pseudomonas putida Isolate
}

\author{
Satyendra Kumar Garg ${ }^{1 *}$, Siddhi Garg ${ }^{2}$, Manikant Tripathi ${ }^{1}$, Kshitindra Singh $^{1}$ \\ ${ }^{1}$ Centre of Excellence \& DST-FIST supported Department of Microbiology, Dr. Ram Manohar Lohia Avadh \\ University, Faizabad-224001, U.P., India. \\ ${ }^{2}$ Wadia Institute of Himalayan Geology, Dehradun, Uttarakhand, India \\ Email: sk_garg001@yahoo.com
}

\begin{abstract}
In this study, Pseudomonas putida, a psychrotrophic isolate, has been employed for biological treatment of tannery effluent. The physicochemical parameters of tannery effluent were analysed. The dilution (1:1) of effluent, its supplementation with nutrients (e.g., glucose, yeast extract, peptone, each at $0.5 \%, \mathrm{w} / \mathrm{v})$ and augmentation with $P$. putida test strain was done for bioremediation studies at natural $\mathrm{pH}$ 8.0. The efficient growth (OD 0.582), $\mathrm{Cr}^{6+}$ removal (61.0\%), decolorization $(60.1 \%$ ) and dechlorination (87.5\%) were observed in diluted effluent during $96-120 \mathrm{~h}$ incubation in shake flask trial. Box-Behnkem design suggested simultaneous dechlorination (95.8\%) and $\mathrm{Cr}^{6+}$ removal (63.5\%) in nutrients supplemented plus P. putida augmented only within $72 \mathrm{~h}$ incubation. The efficiency of bioremediation further enhanced in bioreactor. A direct correlation existed between chromate reductase activity and distribution of reduced chromium in different cell fractions and culture supernatant. Further enhanced dechlorination $(68.2 \%)$ by $14.7 \%$ and $\mathrm{Cr}^{6+}$ removal $(72.7 \%)$ by $6.5 \%$ employing immobilized co-culture ( $P$. putida and Bacillus cereus) as compared to bioremediation by single immobilized $P$. putida biomass. High extent of effluent bioremediation by immobilized biomass offer an attractive future of $P$. putida biomass for eco-friendly in situ bioremediation of tannery wastewater.
\end{abstract}

Keywords: Bioaugmentation, box behnkem design, immobilization, Psuedomonas putida, tannery effluent.

\section{Introduction}

Tanneries constitute one of the most polluting industries causing chromium and chloroorganics' pollution in the environment. There are more than 2500 tanneries in India, and most of them $(\sim 80 \%)$ are engaged in chrom tanning process [1]. The wastewater containing huge amount of organic matter (BOD), chemical oxygen demand (COD), color, sodium sulphide, nitrate, chloride, suspended solids $[2,3]$, phenolics, tannins and heavy metals, particularly $\mathrm{Cr}^{6+}$, is discharged into the environment which not only causes soil and water pollution but also serious threat to human health. When $\mathrm{Cr}^{6+}$ enters the food chain, it causes skin irritation, eardrum perforation, nasal irritation, ulceration and lung sarcoma in humans and animals [4]. Toxic effects of chromium are valence dependent. $\mathrm{Cr}^{6+}$ is highly soluble, mutagenic and carcinogenic whereas, $\mathrm{Cr}^{3+}$ is less soluble and hence less toxic [5]. In addition, it is well known that leather industries generate complex wastewater containing not only chromium but also other toxic compounds like phenol and its derivatives [6,7]. Phenolic compounds also contribute to offflavor problems in drinking and food processing waters.

The routine abatement mechanism for chromium pollution generally involves reduction of $\mathrm{Cr}^{6+}$ to $\mathrm{Cr}^{3+}$, and subsequent precipitation of less soluble chromium at or near neutral $\mathrm{pH}$ [8]. There are several methods for removal of chromium from the tanning wastewater. Conventional physicochemical methods such as electrochemical treatment, ion-exchange, precipitation, reverse osmosis, evaporation and oxidation/reduction are neither cost effective nor eco-friendly for chromium removal from tannery effluent [9]. Furthermore, they lead to generation of secondary sludge. Hence, more practically feasible and economical methods are being explored. In this context, bioremediation is an option that offers the possibility to destroy or render harmless various contaminants using biological activities, which generally have high public acceptance. Bacterial potential for enzymatic reduction of $\mathrm{Cr}^{6+}$ to $\mathrm{Cr}^{3+}$ offers an eco- 
friendly alternate for treatment of contaminated sources. An extensive literature is available on individual bioremediation of $\mathrm{Cr}^{6+}$ and biodegradation of chloroorganics either by single organism or consortium. However, very limited research has been carried out on simultaneous bioremediation of dual or multiple contaminants coexisting in the environment. Industrial effluents containing toxic organic compounds and other heavy metals generally create hindrance in the growth and bioremediation of chromium by the microorganisms.

This research is, therefore, aimed to judge the efficacy of a psychrotrophic Pseudomonas putida SKG1 isolate, for the first time, for simultaneous decolorization, dechlorination of chloroorganics and remediation of $\mathrm{Cr}^{6+}$ from real tannery effluent under varied experimental conditions at flask as well as bench-scale bioreactor levels. Response surface methodology (RSM) was also employed to assess the interactive effects of process parameters on bioremediation of tannery effluent. The chromium reductase activity and distribution of reduced chromium in cell biomass and culture supernatant was studied to establish any correlation between the two determinations. Additionally, the tannery effluent bioremediation was attempted with $P$. putida immobilized biomass alone and also coculturing with $B$. cereus RMLAU1 isolate.

\section{Materials and Methods}

\subsection{Bacterial Culture}

A psychrotrophic Pseudomonas putida SKG-1 (MTCC 10510; NCBI GenBank accession number HQ259593), isolated previously in our laboratory from dairy sludge, was employed in the present study. The bacterium was sub-cultured and maintained on glucose yeast extract (GYE) agar slants (pH 8.0) and stored at $4^{\circ} \mathrm{C}$.

\subsection{Inoculum Preparation}

The bacterial inoculum was prepared in $100 \mathrm{ml}$ sterilized GYE broth [(w/v) $0.5 \%$ glucose, $0.5 \%$ yeast extract and $0.5 \%$ peptone in distilled water] in $500 \mathrm{ml}$ Erlenmeyer flasks by transferring a loop full of $P$. putida isolate, and incubated at $30^{\circ} \mathrm{C}$ for $24 \mathrm{~h}$ in an incubator shaker [150 revolutions per minute (rpm)]. The inoculum size used for decolorization and bioremediation study of real tannery effluent was $4.0 \%$ $(\mathrm{v} / \mathrm{v})$ of the above test culture [optical density (OD) $\mathrm{A}_{620} 1.13$ containing $2.8 \times 10^{6}$ colony forming units (cfu) $\left.\mathrm{ml}^{-1}\right]$.

\subsection{Culture Conditions}

The tannery effluent bioremediation experiments were performed with unsterilized effluent medium. Different experimental sets were designed with undiluted and diluted (1:1 \& 3:1 effluent:distilled water) tannery effluent with four combinations: Set-I: nutrients unsupplemented (US) and unaugmented (UA); Set-II: nutrients unsupplemented (US) but augmented (A) with $1.0 \%$ (v/v) P. putida culture; Set-III: nutrients supplemented $(\mathrm{S})[\mathrm{w} / \mathrm{v}, 0.5 \%$ glucose, $0.5 \%$ yeast extract and $0.5 \%$ peptone] but unaugmented (UA) with P. putida culture; and Set-IV: nutrients supplemented (S) as above plus augmented (A) with $P$. putida culture at natural $\mathrm{pH}$ of effluent. The Erlenmeyer flasks were incubated at previously optimized $30^{\circ} \mathrm{C}$ for $120 \mathrm{~h}$ in an incubator shaker (150 rpm). Bacterial growth, decolorization, dechlorination, $\mathrm{Cr}^{6+}$ removal and $\mathrm{pH}$ change of the effluent were measured periodically at $24 \mathrm{~h}$ interval up to 120 h incubation.

\subsection{Statistical Modeling for $\mathrm{Cr}^{6+}$ Removal and Chloroorganics' Dechlorination}

Box-Behnken design was adapted to define the nature of response surface in the experimental region, and to identify the optimal level of three most significant conventionally optimized variables, viz., glucose $(A)$, yeast extract $(B)$ and peptone $(C)$. The experimental design was generated and analyzed by computational software (Design Expert Version 8.0.5.1). The effect of each parameter on $\mathrm{Cr}^{6+} \mathrm{removal}$ and chloroorganics' dechlorination was studied at three different levels $(-1,0$ and +1$)$ with minimum, 
central and maximum values (Table 1), and seventeen (17) experimental setups were obtained.

Table 1. Experimental range and the levels of three independent variables employed in RSM.

\begin{tabular}{l|l|l|l}
\hline Variables & \multicolumn{3}{|l}{ Levels } \\
\cline { 2 - 4 }$(\%, \mathrm{w} / \mathrm{v})$ & -1 & 0 & +1 \\
\hline Glucose & 0.4 & 0.6 & 0.8 \\
\hline Yeast extract & 0.4 & 0.6 & 0.8 \\
\hline Peptone & 0.2 & 0.4 & 0.6 \\
\hline
\end{tabular}

A second order polynomial equation was used, and the data were fitted in the equation by multiple regression procedure. This resulted in an empirical model. The model equation for analysis is as follows:

$$
Y=\beta o+\sum \beta n X n+\sum \beta n n X n 2+\sum \beta n m X n X m
$$

where, $\mathrm{Y}$ is the predicted response, $\beta$ o offset term, $\beta \mathrm{n}$ linear coefficient, $\beta \mathrm{nn}$ squared coefficient, $\beta \mathrm{nm}$ interaction coefficient, $\mathrm{Xn}$ is the $\mathrm{nth}$ independent variable, $\mathrm{Xn} 2$ squared effect and $\mathrm{XnXm}$ interaction effects. For three variable systems, the model equation is:

$$
\begin{aligned}
& Y=\beta o+\beta 1 A+\beta 2 B+\beta 3 C+\beta 11 A 2+\beta 22 B 2 \\
& +\beta 33 C 2+\beta 12 A B+\beta 13 A C+\beta 23 B C
\end{aligned}
$$

The predicted values for $\mathrm{Cr}^{6+}$ removal and chloroorganics' dechlorination were obtained by applying quadratic model.

\subsection{Bench-scale Bioreactor Level Bioremediation of Tannery Effluent}

Based on the RSM results, the higher level (w/v) of glucose $(0.8 \%)$, yeast extract $(0.6 \%)$ and peptone $(0.6 \%)$ at $\mathrm{pH} 8.0$ and $30^{\circ} \mathrm{C}$, decolorization, dechlorination and $\mathrm{Cr}^{6+}$ removal were performed in a stirred tank bioreactor at fixed agitation speed $(125 \mathrm{rpm})$ and aeration rate 0.4 volume of air per volume of liquid per minute (vvm) by P. putida SKG-1 plus native effluent microflora. The bacterial growth, decolorization, dechlorination and $\mathrm{Cr}^{6+}$ removal were assessed as per the analytical determinations.

\subsection{Chromate Reductase Activity}

Preparation of cell-free extract and chromate reductase assay were performed as per the slightly modified method of Ilias et al. [10]. The bacterial cells grown in effluent broth (100 ml) were harvested during the exponential growth phase $(48 \mathrm{~h})$ and centrifuged at $10000 \mathrm{rpm}\left(4^{\circ} \mathrm{C}\right)$ for $10 \mathrm{~min}$. The culture supernatant was collected and assayed for soluble protein and chromate reductase activity. The cells' pellet was suspended in $5.0 \mathrm{ml}$ phosphate buffer $(50 \mathrm{mM}, \mathrm{pH} 7.0)$, kept in an ice bath $\left(4{ }^{\circ} \mathrm{C}\right)$ and disrupted with an ultrasonicator at $30 \mathrm{sec}$ pulses. The treatment was repeated five times at an interval of $30 \mathrm{sec}$. After sonication, the cell lysate was centrifuged at $16000 \mathrm{rpm}\left(4^{\circ} \mathrm{C}\right)$ for $30 \mathrm{~min}$. and cell-free extract was filtered through nitrocellulose membrane (pore size $0.2 \mu \mathrm{M}$ ) to get cytosolic fraction, which was then transferred to a fresh tube and kept in an ice bath. Cell debris was re-suspended in $5.0 \mathrm{ml}$ phosphate buffer and kept in an ice bath. Boiled culture supernatant, cell debris and cytosolic fraction served as controls. The chromate reductase activity was assayed in reaction mixture containing $0.5 \mathrm{ml}$ enzyme solution (culture supernatant, cell debris and cytosolic fraction), $0.5 \mathrm{ml}$ of $50 \mathrm{mM}$ phosphate buffer and $\mathrm{K}_{2} \mathrm{Cr}_{2} \mathrm{O}_{7}$ as $\mathrm{Cr}^{6+}$ at $3.4 \mathrm{\mu M}$ final concentration. The reaction mixture was incubated at $30^{\circ} \mathrm{C}$ for $30 \mathrm{~min}$. The reaction was stopped by adding $0.2 \mathrm{ml}$ of $20 \%$ trichloroacetic acid. $\mathrm{Cr}^{6+}$ reduction was measured by estimating the decrease in $\mathrm{Cr}^{6+}$ concentration in the reaction mixture using 1,5-diphenyl carbazide method. One unit of enzyme activity was defined as $1.0 \mu \mathrm{M}$ of $\mathrm{Cr}^{6+}$ reduced $\mathrm{min}^{-1}$. Protein was estimated as per Bradford [11] method using BSA as standard.

\subsection{Immobilization of Cell Biomass for Effluent Bioremediation}

Sodium alginate suspension $(4.0 \%, \mathrm{w} / \mathrm{v})$ was prepared as per the method of Lopez et al. [12]. Further, the immobilized $P$. putida beads were used for unsterilized tannery effluent bioremediation study at 
shake flask level. The charging rate of beads was 20 beads per $25 \mathrm{ml}$ effluent. The effluent bioremediation was also performed with augmented co-culture containing $B$. cereus plus $P$. putida isolates. In the study, Bacillus cereus was employed as a part of coculture due to its bioremediation ability. The strain was previously isolated from treated tannery effluent [13, 14], and was capable for simultaneous bioremediation of pentachlorophenol and $\mathrm{Cr}^{6+}$ in minimal salt medium. This bioremediation study employing co-culture was performed at bioreactor level.

\subsection{Elution Cycles}

The elution of chromium was performed with slightly modified method of Srinath et al. [15]. Briefly, the beads were contacted with $100 \mathrm{ml}$ of $0.1 \mathrm{M} \mathrm{H}_{2} \mathrm{SO}_{4}$ for $12 \mathrm{~h}$ under shaking (150 rpm). The total and hexavalent chromium contents in the eluent were analyzed. Subsequently after elution, the immobilized biomass was washed for 15 min with a solution of $0.1 \mathrm{M} \mathrm{CaCl}$ containing $0.1 \mathrm{M} \mathrm{MgSO}_{4}$. Thereafter, the immobilized biomass was washed thrice with deionized water. This regenerated immobilized biomass was used for next $\mathrm{Cr}^{6+}$ bioremediation cycle. The same procedure was repeated for subsequent cycles.

\subsection{Analytical Determinations}

\subsubsection{Bacterial Growth}

The bacterial growth, in terms of absorbance $\left(\mathrm{A}_{620}, 1.0 \mathrm{~cm}\right.$ cuvette; Systronics UV-Vis 117), was recorded periodically at $24 \mathrm{~h}$ interval in different sets of experiments.

\subsubsection{Color Units}

The standard method [16] was employed for measuring the intensity of effluent color (as color units), before and after treatment for tannery wastewater [17].

\subsubsection{Chloride Ions}

The extent of PCP bioremediation was determined by estimation of chloride ions released in the culture supernatant [18]. The chloride ions released, were quantified by extrapolating against the standard curve of sodium chloride.

\subsubsection{Total Chromium and Hexavalent Chromium $\left(\mathrm{Cr}^{6+}\right)$}

The concentration of total chromium was analysed using atomic absorption spectrophotometer (AAS) at $357.9 \mathrm{~nm}$ as per the method of American Public Health Association (APHA) [19]. 1,5-diphenyl carbazide method of APHA [19] was followed for the estimation of $\mathrm{Cr}^{6+}$ in the culture supernatant using $\mathrm{UV}$-vis spectrophotometer and was extrapolated against $\mathrm{K}_{2} \mathrm{Cr}_{2} \mathrm{O}_{7}$ standard curve at $540 \mathrm{~nm}$.

\subsection{Physicochemical Parameters}

The physicochemical parameters were determined as per APHA [19], and an average of triplicate for each experiment is being reported.

\subsection{Statistical Analysis}

All experiments were performed in triplicates. The statistical calculation was done as per the standard method [20], and results are presented as mean $\pm \mathrm{SD}$ values.

\section{$3 \quad$ Results and Discussion}

\subsection{Physicochemical Analyses of Effluent}

Table 2 presents the physicochemical analysis results of diluted (1:1) untreated and bacterially treated tannery effluent. The $\mathrm{pH}$ and temperature are the significant parameters which affect the enzymatic reactions occurring in various cellular organisms. These parameters were within the prescribed limits of minimum national standards. The results further reveal a significant reduction in most of the physicochemical parameters analyzed during the course of bacterial treatment. 
Table 2. Physicochemical and heavy metal analyses of untreated tannery effluent

\begin{tabular}{|c|c|c|c|c|c|}
\hline \multirow{3}{*}{$\begin{array}{l}\text { Physicochemical } \\
\text { parameter/heavy metal }\end{array}$} & \multirow{3}{*}{$\begin{array}{l}\text { Permissible } \\
\text { limit* }\end{array}$} & \multicolumn{4}{|l|}{ Effluent } \\
\hline & & \multicolumn{2}{|l|}{ Untreated } & \multicolumn{2}{|l|}{ Treated } \\
\hline & & Real undiluted & $\begin{array}{l}\text { Diluted } \\
(1: 1) \\
\end{array}$ & $\begin{array}{l}\text { Diluted } \\
(1: 1) \\
\end{array}$ & $\begin{array}{l}\text { Decrease } \\
(\%)\end{array}$ \\
\hline $\mathrm{pH}$ & $5.5-9.0$ & $8.4 \pm 0.1$ & $8.0 \pm 0.1$ & $6.9 \pm 0.1$ & - \\
\hline Temperature & $<35^{\mathrm{O}} \pm 1^{\circ} \mathrm{C}$ & $30 \pm 1.0^{\circ} \mathrm{C}$ & $30 \pm 1.0^{\circ} \mathrm{C}$ & $30 \pm 1.0^{\circ} \mathrm{C}$ & - \\
\hline Total suspended solids $\left(\mathrm{mg} \mathrm{l}^{-1}\right)$ & 600 & $2856 \pm 17.9$ & $1365 \pm 15.7$ & 820 & 39.9 \\
\hline Total dissolved solids $\left(\mathrm{mg} \mathrm{l}^{-1}\right)$ & 2100 & $4370 \pm 32.5$ & $2078 \pm 32.5$ & 1537 & 26.0 \\
\hline Hardness $\left(\mathrm{mgl}^{-1}\right)$ & - & $2195 \pm 21.6$ & $1259 \pm 17.2$ & 815 & 35.3 \\
\hline Oil and grease $\left(\mathrm{mg} \mathrm{l}^{-1}\right)$ & 10.0 & $187 \pm 3.2$ & $88 \pm 3.5$ & 34.7 & 60.6 \\
\hline B.O.D. $\left(\mathrm{mg} \mathrm{l}^{-1}\right)$ & 30.0 & $925 \pm 11.7$ & $502 \pm 22.7$ & 195 & 61.2 \\
\hline C.O.D. $\left(\mathrm{mg} \mathrm{l}^{-1}\right)$ & 250.0 & $2781 \pm 19.0$ & $1327 \pm 41.8$ & 562 & 57.6 \\
\hline $\mathrm{Cr}^{6+}\left(\mathrm{mg} \mathrm{l}^{-1}\right)$ & 0.1 & $141 \pm 1.3$ & 77 & 22.0 & 71.4 \\
\hline Total Cr $\left(\mathrm{mg} \mathrm{l}^{-1}\right)$ & 2.0 & 162 & 83.0 & 79.2 & 4.6 \\
\hline $\mathrm{Fe}\left(\mathrm{mg} \mathrm{l}^{-1}\right)$ & 0.1 & 6.85 & 3.7 & 0.28 & 92.4 \\
\hline $\mathrm{Cu}\left(\mathrm{mg} \mathrm{l}^{-1}\right)$ & 3.0 & 0.71 & 0.24 & $\mathrm{ND}$ & 100 \\
\hline As $\left(\mathrm{mg} \mathrm{l}^{-1}\right)$ & 0.2 & 1.83 & 0.65 & 0.41 & 36.9 \\
\hline $\mathrm{Ni}\left(\mathrm{mg} \mathrm{l}^{-1}\right)$ & 3.0 & 3.96 & 1.92 & $\mathrm{ND}$ & 100 \\
\hline $\mathrm{Zn}\left(\mathrm{mg} \mathrm{l}^{-1}\right)$ & 5.0 & 2.15 & 1.03 & $\mathrm{ND}$ & 100 \\
\hline $\mathrm{Cd}\left(\mathrm{mg} \mathrm{l}^{-1}\right)$ & 2.0 & 0.07 & $\mathrm{ND}$ & $\mathrm{ND}$ & 100 \\
\hline
\end{tabular}

The concentrations of $\mathrm{Cr}^{6+}$ in $1: 1$ diluted untreated tannery effluent were $77 \pm 1.5 \mathrm{mg} \mathrm{l}^{-1}$, which was above the permissible limit; the bacterial treatment ensued $71.4 \% \mathrm{Cr}^{6+}$ reduction (Table 2). According to Indian standards IS: 2296 and IS: 2490, the statutory limit for the discharge of total chromium in the inland surface waters is $2.0 \mathrm{mg} \mathrm{l}^{-1}[9]$. The concentrations $\left(\mathrm{mg} \mathrm{l}^{-1}\right)$ of other heavy metals analyzed in diluted untreated effluents were: iron (3.7), copper (0.24), arsenic (0.65), nickel (1.92) and zinc (1.03), of which $\mathrm{Fe}$, As and $\mathrm{Ni}$ were above the permissible limits. The level of cadmium was undetectable in 1:1 diluted untreated effluent while, copper, nickel and zinc were completely remediated from the bacterially treated effluent. On the other hand, the levels of iron and arsenic were reduced by 92.4 and $36.9 \%$, respectively, after bacterial treatment.

\subsection{Tannery Effluent Bioremediation}

The initial trial was performed to know whether sterilization of tannery effluent was necessary for bioremediation study. The findings revealed that bioremediation efficiency was far better with the unsterilized than the sterilized effluent (not shown). This was mainly due to the presence of native effluent microflora, which also plays a significant role in the bioremediation process, and the same is eliminated upon sterilization. Furthermore, the sterilization of bulk effluent would be tedious, cost prohibitive and energy intensive and hence, practically infeasible at industrial level.

\subsection{Bioremediation of Undiluted Tannery Effluent}

P. putida SKG-1 isolate was employed for the treatment of tannery effluent under various sets of experimental conditions and the results are depicted in Fig. 1a, b. The results indicate that the native microflora present in effluent was capable of bioremediation (Set-I), and the extent of biotreatment was best in nutrients supplemented plus P. putida augmented tannery effluent (Set-IV).

\subsection{Bioremediation of Diluted Tannery Effluent}

Owing to the poor efficiency of bioremediation in undiluted tannery effluent, it was variedly diluted (dilution 1:1 \& 3:1), and the determinations were evaluated in Sets I-IV experiments. The comparison of 
respective results in 1:1 (Fig. 2a) and 3:1 (Fig. 3a) diluted tannery effluents revealed that maximum combined growth of native microflora plus augmented P. putida (OD 0.582 \& 0.377 ) and $\mathrm{Cr}^{6+}$ removal $^{2}$ $(61.0 \& 46.9 \%)$ were observed in both the diluted effluents supplemented with $0.5 \%(\mathrm{w} / \mathrm{v})$ each of glucose + peptone + yeast extract at $96 \mathrm{~h}$ incubation; whereas, effluent decolorization $(60.1 \& 40.0 \%)$ and dechlorination (87.5 \& 60.7\%) were maximum at $120 \mathrm{~h}$ incubation (Figs. 2b \& 3b). Since the bioremediation efficiency in 3:1 diluted tannery effluent was less than 1:1 diluted effluent, the latter was preferred for further experiments on tannery effluent biotreatment.An appreciable extent of growth, decolorization, dechlorination, and $\mathrm{Cr}^{6+}$ removal in diluted as compared to undiluted effluent could be due to reduced toxicity of metals and organic pollutants upon dilution. Contrary to our findings, Paisio et al. [7] observed highest growth of Rhodococcus sp. CS1 in pure tannery wastewater as compared to diluted (25, 50 and 75\%) effluent. They reported complete phenol degradation (from initial $17.5 \mathrm{mg} \mathrm{l}^{-1}$ concentration) in tannery wastewater by CS1 strain after $9 \mathrm{~h}$ incubation; whereas, only $20 \%$ phenol degradation was achieved by native tannery effluent microflora in $9 \mathrm{~h}$.

It may be summarized from the aforementioned results that dilution is necessary for reducing the toxicity exerted on microflora by some native constituents of the effluent. In general, the order of growth, decolorization, dechlorination and $\mathrm{Cr}^{6+}$ removal in all four sets of experiments in undiluted and diluted effluents was: effluent $(\mathrm{E})+$ nutrients supplemented $(\mathrm{S})+\operatorname{augmented}(\mathrm{A})>\mathrm{E}+\mathrm{S}>\mathrm{E}+\mathrm{A}>\mathrm{E}$ (Figs. 1-3). The better bioremediation response in unaugmented effluent supplemented with exogenous nutrients (Set-III) than in augmented-nutrients unsupplemented with effluent (Set-II) was due to the cometabolism of organic nutrients present in tannery effluent along with utilization of externally added carbon and nitrogen sources by the native effluent microflora, thereby resulting in significant bioremediation.Some bioremediation effected in unaugmented-nutrients unsupplemented (Set-I) effluent reaffirm the role of native effluent microflora in the metabolism of organic compounds naturally present in tannery effluent. The extent of bioremediation was significantly higher in nutrients supplemented plus augmented undiluted as well as diluted effluents in all the four sets of experiments, thereby underlining the requirement of both for efficient bioremediation of tannery effluent. Therefore, diluted (1:1) tannery effluent augmented with $P$. putida strain and supplemented with glucose, peptone and yeast extract was selected for further bioremediation experiments. Bhattacharya et al. [21] evaluated simultaneous removal of phenol and $\mathrm{Cr}^{6+}$ from tannery effluent employing a consortium of four naturally isolated bacterial strains including Acinetobacter sp. B9 and Arthrobacter sp. B2. They reported that application of bacterial consortia to effluent $(\mathrm{pH} 4.6)$ resulted in 100 and $78 \%$ removal of initial $47 \mathrm{mg} \mathrm{l}^{-1}$ phenol and $16 \mathrm{mg} \mathrm{l}^{-1} \mathrm{Cr}^{6+}$, respectively at $96 \mathrm{~h}$ of treatment. However, Akpomie and Ejechi [22] studied the bioremediation efficiency of a combination of cow dung and a microbial consortium (Pseudomonas aeruginosa, Penicillium chrysogenum and Aspergillus niger) in soil contaminated with tannery effluent. They reported that levels of phenol, sulphide and ammonium nitrogen in contaminated soil were significantly reduced to permissible levels after treatment with microbial consortium, cow dung or combination of microbial consortium and cow dung.

\subsection{RSM Optimization of Process Parameters for Effluent Bioremediation}

This is the first report on statistical optimization of process parameters for simultaneous bacterial decolorization, dechlorination of chloroorganics and $\mathrm{Cr}^{6+}$ removal from tannery effluent medium by $P$. putida augmentation. Interactive effects of the most important conventionally optimized factors, viz., glucose, peptone and yeast extract were examined by RSM using Box-Behnken design. Table 3 presents the predicted responses of Box-Behnken design on the basis of polynomial equation.

Response surface curves for the variation in PCP dechlorination and $\mathrm{Cr}^{6+}$ removal were constructed, and are depicted in Figs. 4 and 5. In each set, two variables varied within their experimental range, while other two variables remained constant at zero level. Figs. 4a and 5a depict chloroorganics' dechlorination and $\mathrm{Cr}^{6+}$ removal with respect to glucose versus yeast extract concentration. From the interaction response, dechlorination and $\mathrm{Cr}^{6+}$ removal increased with increasing glucose concentration (Fig. 4a). This suggested a demand for higher concentration of glucose. Fig. 4a shows the optimal values for glucose 0.8 and yeast extract $0.6 \mathrm{mg} \mathrm{l}^{-1}$. Figs. $4 \mathrm{~b}$ and $5 \mathrm{~b}$ depict significant effect of glucose on both the determinations. With an increase in glucose level $(0.4-0.8 \%, \mathrm{w} / \mathrm{v})$, the bioremediation of both the pollutants increased. However, maximum chloroorganics' dechlorination (95.8\%) and $\mathrm{Cr}^{6+}$ bioremediation $(63.5 \%)$ was achieved at $0.8 \%$ glucose and $0.6 \%$ peptone. 
Table 3. Experimental designs used in RSM studies using three independent variables showing observed and predicted values.

\begin{tabular}{|c|c|c|c|c|c|c|c|}
\hline \multirow[t]{2}{*}{$\begin{array}{l}\text { Standard } \\
\text { Order }\end{array}$} & \multirow{2}{*}{$\begin{array}{l}\text { Factor A } \\
\text { (Glucose, } \\
\% \mathrm{w} / \mathrm{v})\end{array}$} & \multirow{2}{*}{$\begin{array}{l}\text { Factor B } \\
\text { (yeast extract, } \\
\% \mathrm{w} / \mathrm{v} \text { ) }\end{array}$} & \multirow{2}{*}{$\begin{array}{l}\text { Factor C } \\
\text { (peptone, } \\
\% \mathrm{w} / \mathrm{v})\end{array}$} & \multicolumn{2}{|c|}{$\begin{array}{l}\mathrm{Cr}^{6+} \text { removal } \\
(\%)\end{array}$} & \multicolumn{2}{|c|}{$\begin{array}{l}\text { Chloroorganics' } \\
\text { dechlorination }(\%)\end{array}$} \\
\hline & & & & $\begin{array}{l}\text { Observed } \\
\text { response }\end{array}$ & $\begin{array}{l}\text { Predicted } \\
\text { response }\end{array}$ & $\begin{array}{l}\text { Observed } \\
\text { response }\end{array}$ & $\begin{array}{l}\text { Predicted } \\
\text { response }\end{array}$ \\
\hline 1 & 0.40 & 0.40 & 0.40 & 48.8 & 48.67 & 87.5 & 87.25 \\
\hline 2 & 0.80 & 0.40 & 0.40 & 56.1 & 56.20 & 91.6 & 91.38 \\
\hline 3 & 0.40 & 0.80 & 0.40 & 52.4 & 52.30 & 89.6 & 89.83 \\
\hline 4 & 0.80 & 0.80 & 0.40 & 58.9 & 59.02 & 93.8 & 94.05 \\
\hline 5 & 0.40 & 0.60 & 0.20 & 52.9 & 53.14 & 89.6 & 89.84 \\
\hline 6 & 0.80 & 0.60 & 0.20 & 57.8 & 57.81 & 93.8 & 94.01 \\
\hline 7 & 0.40 & 0.60 & 0.60 & 53.7 & 53.69 & 91.6 & 91.39 \\
\hline 8 & 0.80 & 0.60 & 0.60 & 63.5 & 63.26 & 95.8 & 95.56 \\
\hline 9 & 0.60 & 0.40 & 0.20 & 53.4 & 53.29 & 89.6 & 89.61 \\
\hline 10 & 0.60 & 0.80 & 0.20 & 56.2 & 56.06 & 91.6 & 91.14 \\
\hline 11 & 0.60 & 0.40 & 0.60 & 55.7 & 55.84 & 89.6 & 90.06 \\
\hline 12 & 0.60 & 0.80 & 0.60 & 59.4 & 59.51 & 93.8 & 93.79 \\
\hline 13 & 0.60 & 0.60 & 0.40 & 56.1 & 56.18 & 93.8 & 93.80 \\
\hline 14 & 0.60 & 0.60 & 0.40 & 56.2 & 56.18 & 93.8 & 93.80 \\
\hline 15 & 0.60 & 0.60 & 0.40 & 56.1 & 56.18 & 93.8 & 93.80 \\
\hline 16 & 0.60 & 0.60 & 0.40 & 56.3 & 56.18 & 93.8 & 93.80 \\
\hline 17 & 0.60 & 0.60 & 0.40 & 56.2 & 56.18 & 93.8 & 93.80 \\
\hline
\end{tabular}

The response in Figs. 4c and 5c reveal maximum dechlorination and $\mathrm{Cr}^{6+}$ removal at $0.6 \%$ peptone and $0.6 \%$ yeast extract concentration when glucose was kept at constant optimized value $(0.8 \%, \mathrm{w} / \mathrm{v})$. This accorded a run number of 8 , which is considered as the optimal condition of test variables (Table 3). The RSM results reveal maximum experimental $95.8 \%$ PCP dechlorination and $63.5 \% \mathrm{Cr}^{6+}$ removal $^{2}$ at $(\mathrm{w} / \mathrm{v})$ glucose $0.8 \%(+1$ in coded unit), yeast extract $0.6 \%(0$ in coded unit) and peptone at $0.6 \%(+1$ in coded unit), which were very close to respective $95.5 \%$ and $63.26 \%$ remediation of both the toxicants predicted by Box-Behnken design with initial $48 \mathrm{mg}$ chloride $\mathrm{l}^{-1}, 78 \mathrm{mg} \mathrm{Cr}^{6+} \mathrm{l}^{-1}$, $\mathrm{pH} 8.0$ and temperature $30^{\circ} \mathrm{C}$. The experimental findings suggest that these optimized parameters using RSM strongly support the chloroorganics and $\mathrm{Cr}^{6+}$ remediation by $P$. putida SKG-1. Other researchers have reported RSM a better approach for optimization of single chromium bioremediation [23].

\subsection{Bench-Scale Bioreactor Level Bioremediation of Tannery Effluent}

Tannery effluent bioremediation was also performed in a stirred tank bioreactor operating in a batch system, where good containment and environmental control may allow a fast and cost-effective treatment. In this trial, $4.0 \%(\mathrm{v} / \mathrm{v})$ dose of SKG-1 strain was augmented for bioremediation of 1:1 diluted tannery effluent supplemented with RSM optimized nutrients (w/v, $0.8 \%$ of glucose, $0.6 \%$ each of yeast extract and peptone) at previously optimized [24] agitation speed of $125 \mathrm{rpm}$ and $0.4 \mathrm{vvm}$ aeration rate. The results in Figs. 6a\&b reveal that the extent of decolorization, dechlorination and $\mathrm{Cr}^{6+}$ removal directly corresponded with the bacterial growth throughout the incubation period up to $72 \mathrm{~h}$ incubation. The efficiency of bioremediation in bioreactor was higher as compared to flask trial during $72 \mathrm{~h}$ incubation: decolorization $(62.6 \%)$ enhanced by $5.4 \%$, dechlorination $(97.9 \%)$ by $2.1 \%$ and $\mathrm{Cr}^{6+}$ removal $(65.4 \%$ ) by $2.6 \%$ (during $60 \mathrm{~h}$ ) at initial color $187 \mathrm{Pt}$-Co units, $48 \mathrm{mg}$ chloride ions and $78 \mathrm{mg}$ $\mathrm{Cr}^{6+} \mathrm{l}^{-1}$ effluent. Ganguli and Tripathi [25] evaluated the ability of P. aeruginosa strain, isolated from tannery effluent, to survive and reduce chromate in effluents from a tannery and electroplating unit. The isolate survived in the native tannery effluent, but the count sharply declined in both native and diluted (200X) electroplating effluent. Addition of carbon, nitrogen and phosphorus sources enhanced 
bacterial cell number in both tannery and diluted electroplating effluents, and increased cell numbers directly correlated with enhanced chromate reduction in both the effluents.

\subsection{Distribution of Reduced Chromium and Chromate Reductase in Different Fractions}

Table 4 reveals the extent of reduced chromium $\left(\mathrm{Cr}^{3+}\right)$ distribution in culture supernatant and biomass of $P$. putida plus native microflora, and was found to be present in both. The results further indicate that out of total $\mathrm{Cr}^{6+}$ remediated (51 mg of initial $78 \mathrm{mg} \mathrm{l}^{-1}$, i.e., $65.4 \%$ ) from effluent medium at $60 \mathrm{~h}$, $91.3 \% \mathrm{Cr}^{6+}$ was reduced to $\mathrm{Cr}^{3+}$, of which $36.3 \%$ was detected in culture supernatant and $55 \%$ in the bacterial biomass (Table 4). The chromate reductase activity in treated tannery effluent (1:1 diluted) from bioreactor trial was measured to assess the enzymatic conversion of $\mathrm{Cr}^{6+}$ to $\mathrm{Cr}^{3+}$ by augmented $P$. putida plus native effluent microflora. Table 5 reveals the presence of enzyme activity in culture supernatant, cytosolic fraction as well as in the cell debris containing augmented P. putida strain plus native tannery effluent microflora. The maximum enzyme activity in cells' cytosolic fraction $(54.8 \%)$ was followed by the activity in culture supernatant $(41.1 \%)$ and cellular debris $(4.1 \%)$. This shows that chromate reductase activity was mainly associated with the soluble fraction of bacterial cells. The distribution of $\mathrm{Cr}^{3+}$ in culture supernatant and bacterial biomass (Table 4) correlates directly with the extent of chromate reductase activity in culture supernatant and cytosolic fraction (Table 5).

Table 4. Distribution of reduced chromium $\left(\mathrm{Cr}^{3+}\right)$ between culture supernatant and bacterial biomass in bioreactor trial.

\begin{tabular}{|c|c|c|c|c|c|c|c|c|c|c|c|}
\hline \multirow{3}{*}{$\begin{array}{l}\text { Time } \\
\text { (h) }\end{array}$} & \multirow{3}{*}{$\begin{array}{l}\% \mathrm{Cr}^{6+} \\
\text { Removal }\end{array}$} & \multicolumn{4}{|c|}{ Culture supernatant } & \multicolumn{5}{|l|}{ Biomass } & \multirow{3}{*}{$\begin{array}{l}\text { Total } \\
\text { reduced } \\
\left(\mathrm{Cr}^{3+}\right) \\
(\%) \\
\end{array}$} \\
\hline & & \multirow[t]{2}{*}{$\begin{array}{l}\text { Total Cr } \\
\left(\mathrm{mg} \mathrm{l}^{-1}\right)\end{array}$} & \multirow{2}{*}{$\begin{array}{l}\text { Residual } \\
\mathrm{Cr}^{6+} \\
\left(\mathrm{mg} \mathrm{l}^{-1}\right) \\
\end{array}$} & Redu & $\mathrm{Cr}^{3+}$ & \multirow[t]{2}{*}{$\begin{array}{l}\text { Total Cr } \\
\left(\mathrm{mg} \mathrm{l}^{-1}\right)\end{array}$} & \multicolumn{2}{|c|}{$\mathrm{Cr}^{6+}$} & \multicolumn{2}{|c|}{$\begin{array}{l}\text { Reduced } \\
\mathrm{Cr}^{3+}\end{array}$} & \\
\hline & & & & \multicolumn{2}{|c|}{$\left(\mathrm{mg} \mathrm{l}^{-1}\right)(\%)$} & & \multicolumn{2}{|c|}{$\left(\mathrm{mg} \mathrm{l}^{-1}\right)(\%)$} & \multicolumn{2}{|c|}{$\left(\mathrm{mg} \mathrm{l}^{-1}\right)(\%)$} & \\
\hline 24 & 24.3 & 63.2 & 59 & 4.2 & 22.1 & 10.5 & ND & ND & 9.5 & 55.3 & 77.4 \\
\hline 48 & 58.9 & 44.0 & 32 & 12.0 & 26.0 & 25.8 & ND & $\mathrm{ND}$ & 22.3 & 56.1 & 82.1 \\
\hline 60 & 65.4 & 45.5 & 27 & 18.5 & 36.3 & 28.1 & $\mathrm{ND}$ & $\mathrm{ND}$ & 28.1 & 55.0 & 91.3 \\
\hline 72 & 62.8 & 49.3 & 29 & 20.3 & 41.5 & 24.5 & $\mathrm{ND}$ & ND & 24.5 & 50.0 & 91.5 \\
\hline
\end{tabular}

ND: not detectable, standard deviation values of calculated data are $<5.0 \%$.

Table 5. Chromate reductase activity in different cell fractions of $P$. putida coculture in diluted tannery effluent.

\begin{tabular}{|c|c|c|c|c|}
\hline Cell fraction & $\begin{array}{l}\text { Total chromate reductase } \\
\text { activity }\left(\mu \mathrm{M} \mathrm{min}{ }^{-1}\right)\end{array}$ & $\begin{array}{l}\text { Chromate reductase } \\
\text { activity }(\%)\end{array}$ & $\begin{array}{l}\text { Total protein } \\
(\mathrm{mg})\end{array}$ & $\begin{array}{l}\text { Specific activity } \\
\left(\mu \mathrm{M} \mathrm{min}{ }^{-1} \mathrm{mg}^{-1} \text { protein }\right)\end{array}$ \\
\hline $\begin{array}{l}\text { Culture } \\
\text { supernatant }\end{array}$ & 3.6 & 41.1 & 2.18 & 1.65 \\
\hline Cytosolic fraction & 4.8 & 54.8 & 0.59 & 8.13 \\
\hline Cell debris & 0.35 & 4.1 & 0.22 & 1.59 \\
\hline
\end{tabular}

\subsection{Bioremediation of Tannery Effluent by Immobilized Biomass}

In commercial processes, the physical characteristics of free cells such as small size, low density, poor mechanical strength/rigidity and solid-liquid separation might be problematic in the bioremoval of effluent contaminants [9]. Furthermore, free cells often experience excessive $\mathrm{Cr}^{6+}$ toxicity, and undergo cell damage when they are employed for bioremediation. Free cells may, therefore, be more prone to toxicity from chromate and other metals as compared to immobilized cells, which may have some protection from the toxic compounds present in the effluent [26]. Therefore, the experiments were performed to evaluate the tannery effluent bioremediation ability of immobilized P. putida cells using previously optimized [24] sodium alginate $(4.0 \%, \mathrm{w} / \mathrm{v})$ as a support material.

Table 6 reveals maximum decolorization (54.5\%), dechlorination $(89.6 \%)$ and $\mathrm{Cr}^{6+}$ removal $(68.8 \%)$ at initial color $187 \mathrm{Pt}$-Co units, $48 \mathrm{mg}$ chloride ions and $77 \mathrm{mg} \mathrm{Cr}^{6+} \mathrm{l}^{-1}$ by immobilized P. putida biomass 
along with free native effluent microflora within $72 \mathrm{~h}$ incubation. This response was only slightly better than results at $60 \mathrm{~h}$ incubation for all the determinations. The $\mathrm{Cr}^{6+}$ removal by immobilized $P$. putida biomass was enhanced by $5 \%$ compared to free cells. This increased efficiency was due to the better porosity of beads, which allowed free transport of metal ions through the matrix. The immobilized cells were repeatedly used up to four remediation cycles; however, their efficiency decreased after every cycle, and was the minimum in the fourth cycle (Table 6). This could be attributed to the loss of bead integrity leading to disintegration of matrix.

Table 6. Decolorization, dechlorination and $\mathrm{Cr}^{6+}$ removal in tannery effluent augmented with immobilized biomass of P. putida.

\begin{tabular}{|c|c|c|c|c|c|c|c|c|c|c|c|c|c|c|c|c|c|c|c|c|}
\hline \multirow[t]{3}{*}{$\begin{array}{l}\text { Time } \\
\text { (h) }\end{array}$} & \multicolumn{4}{|l|}{$\mathrm{pH}$} & \multicolumn{4}{|c|}{ Growth } & \multicolumn{4}{|c|}{$\begin{array}{l}\text { Color in units } \\
(\% \text { decrease })\end{array}$} & \multicolumn{4}{|c|}{ Chloride in $\mathrm{mg} \mathrm{l}^{-1}$} & \multicolumn{4}{|c|}{$\begin{array}{l}\mathrm{Cr}^{6+} \text { in } \mathrm{mg} \mathrm{l}^{-1} \\
(\% \text { removal })\end{array}$} \\
\hline & \multicolumn{20}{|c|}{ Cycles } \\
\hline & $\mathrm{I}$ & II & III & IV & $\mathrm{I}$ & II & III & IV & $\mathrm{I}$ & II & III & IV & $\mathrm{I}$ & II & III & IV & $\mathrm{I}$ & II & III & IV \\
\hline 0 & 8.0 & 8.0 & 8.0 & 8.0 & ND & $\mathrm{ND}$ & ND & ND & $\begin{array}{l}187 \\
(0) \\
\end{array}$ & $\begin{array}{l}187 \\
(0)\end{array}$ & $\begin{array}{l}187 \\
(0) \\
\end{array}$ & $\begin{array}{l}187 \\
(0) \\
\end{array}$ & 48 & 48 & 48 & 48 & $\begin{array}{l}77 \\
(0) \\
\end{array}$ & $\begin{array}{l}77 \\
(0) \\
\end{array}$ & $\begin{array}{l}77 \\
(0) \\
\end{array}$ & $\begin{array}{l}77 \\
(0) \\
\end{array}$ \\
\hline 24 & 7.6 & 7.7 & 7.7 & 7.8 & 0.292 & 0.268 & 0.231 & 0.185 & \begin{tabular}{|l|}
124 \\
$(33.7)$ \\
\end{tabular} & $\begin{array}{l}139 \\
(25.6) \\
\end{array}$ & $\begin{array}{l}141 \\
(24.5) \\
\end{array}$ & \begin{tabular}{|l}
140 \\
$(25.1)$
\end{tabular} & 65 & 59 & 57 & 52 & $\begin{array}{l}48 \\
(37.7) \\
\end{array}$ & \begin{tabular}{|l|}
62 \\
$(19.4)$ \\
\end{tabular} & $\begin{array}{l}65 \\
(15.6) \\
\end{array}$ & $\begin{array}{l}72 \\
(7.8) \\
\end{array}$ \\
\hline 36 & 7.4 & 7.5 & 7.6 & 7.5 & 0.440 & 0.386 & 0.347 & 0.293 & $\begin{array}{l}105 \\
(43.9)\end{array}$ & $\begin{array}{l}122 \\
(34.8) \\
\end{array}$ & $\begin{array}{l}129 \\
(31.0) \\
\end{array}$ & $\begin{array}{l}131 \\
(29.9)\end{array}$ & 75 & 67 & 62 & 60 & $\begin{array}{l}39 \\
(49.4) \\
\end{array}$ & \begin{tabular}{|l|}
48 \\
$(37.6)$ \\
\end{tabular} & $\begin{array}{l}52 \\
(32.5) \\
\end{array}$ & $\begin{array}{l}63 \\
(18.2) \\
\end{array}$ \\
\hline 48 & 7.2 & 7.2 & 7.4 & 7.3 & 0.532 & 0.470 & 0.415 & 0.382 & $\begin{array}{l}99 \\
(47.0) \\
\end{array}$ & \begin{tabular}{|l}
108 \\
$(42.2)$ \\
\end{tabular} & $\begin{array}{l}115 \\
(38.5) \\
\end{array}$ & $\begin{array}{l}117 \\
(37.4)\end{array}$ & 83 & 79 & 74 & 71 & $\begin{array}{l}31 \\
(59.8) \\
\end{array}$ & $\begin{array}{l}45 \\
(41.6)\end{array}$ & $\begin{array}{l}49 \\
(36.4)\end{array}$ & $\begin{array}{l}58 \\
(24.6) \\
\end{array}$ \\
\hline 60 & 7.0 & 7.1 & 7.2 & 7.2 & 0.575 & 0.548 & 0.492 & 0.435 & $\begin{array}{l}87 \\
(53.5) \\
\end{array}$ & $\begin{array}{l}95 \\
(49.2) \\
\end{array}$ & $\begin{array}{l}112 \\
(40.1) \\
\end{array}$ & $\begin{array}{l}116 \\
(38.0)\end{array}$ & 90 & 85 & 81 & 77 & $\begin{array}{l}26 \\
(66.2) \\
\end{array}$ & $\begin{array}{l}41 \\
(46.5)\end{array}$ & $\begin{array}{l}47 \\
(40.0) \\
\end{array}$ & $\begin{array}{l}57 \\
(25.9) \\
\end{array}$ \\
\hline 72 & 6.9 & 7.2 & 7.1 & 7.2 & 0.597 & 0.532 & 0.510 & 0.469 & $\left.\begin{array}{l}85 \\
(54.5)\end{array}\right)$ & $\left.\begin{array}{l}92 \\
(54.5)\end{array}\right)$ & $\begin{array}{l}113 \\
(39.5)\end{array}$ & $\begin{array}{l}114 \\
(39.0)\end{array} \mid$ & 91 & 86 & 83 & 78 & $\begin{array}{l}24 \\
(68.8)\end{array}$ & $\begin{array}{l}43 \\
(44.2)\end{array} \mid$ & $\begin{array}{l}48 \\
(37.7)\end{array}$ & $\mid \begin{array}{l}59 \\
(23.4)\end{array}$ \\
\hline
\end{tabular}

(Standard deviation values of calculated data are $<5.0 \%$ )

Other researchers also studied $\mathrm{Cr}^{6+}$ bioremediation using immobilized biomass. Ganguli and Tripathi [27] compared the chromate removal ability of batch culture (free cells) and agarose-alginate immobilized Pseudomonas aeruginosa A2Chr biomass (from initial 10-100 $\mathrm{mg} \mathrm{Cr}^{6+} \mathrm{l}^{-1}$ ) in a minimal medium and electroplating effluent. In batch culture study, the maximum $\mathrm{Cr}^{6+}$ removal of $9.4 \mathrm{mg} \mathrm{l}^{-1}$ occurred at the lowest initial $\mathrm{Cr}^{6+}$ concentration of $10 \mathrm{mg} \mathrm{l}^{-1}$ minimal medium, within $2 \mathrm{~h}$. However, at higher initial $\mathrm{Cr}^{6+}$ concentrations of 50 and $100 \mathrm{mg} \mathrm{l}^{-1}, \mathrm{Cr}^{6+}$ removal was only 7.6 and $2.1 \mathrm{mg} \mathrm{l}^{-1}$, within $2 \mathrm{~h}$. The removal of $\mathrm{Cr}^{6+}$ from electroplating effluent was approximately $25 \%$ lower than removal rates from the minimal medium. Murugesan and Maheswari [28] reported $6.55 \%$ chromium removal efficiency (at an initial $100 \mathrm{ppm} \mathrm{Cr}^{6+}$ concentration) for alginate-immobilized Pseudomonas sp. within 4 h. Benazir et al. [29] compared the chromium remediation efficiencies of Bacillus subtilis, Pseudomonas aeruginosa and Saccharomyces cerevisiae in consortia and in their immobilized forms. The best chromium reduction activity was observed for the $S$. cerevisiae- $P$. aeruginosa consortium, followed by immobilized beads of $S$. cerevisiae and $B$. subtilis- $S$. cerevisiae consortia.

When immobilized biomass of co-culture ( $P$. putida SKG-1 plus B. cereus RMLAU1) was employed for bioremediation of tannery effluent, better response concerning all the above determinations was observed (not shown), as compared to single P. putida immobilized biomass (Table 6). The enhanced extent of decolorization $(68.2 \%)$ by $14.7 \%$ and $\mathrm{Cr}^{6+}$ removal $(72.7 \%)$ by $6.5 \%$ using immobilized coculture was observed, compared to bioremediation of effluent by single immobilized P. putida biomass. The results on tannery effluent remediation by immobilized co-culture reveal that addition of $B$. cereus RMLAU1 strain enhanced the bioremediation efficiency of $P$. putida. There is not even a single report on tannery effluent decolorization, dechlorination and simultaneous $\mathrm{Cr}^{6+}$ removal by immobilized biomass. 


\section{Conclusions}

Scanty research has been attempted for bioremediation of real tannery effluent. The conventional physicochemical and biological techniques are insufficient and economically non-viable for remediation of toxic pollutants present in real effluent. However, the microbial remediation methods are being considered eco-friendly and cost-effective as compared to conventional methods. In our study, high extent of effluent bioremediation at flask and bioreactor levels was evident under optimized cultural and nutritional conditions. It is the first report of real tannery effluent bioremediation by a psychrotrophic $P$. putida. Biostimulation and bioaugmentation enhanced treatment efficiency. Box-Behnkem design suggested extended dechlorination and $\mathrm{Cr}^{6+}$ removal. An increased extent of bioremediation was evident by coculture (P. putida + B.cereus) than P. putida alone. A direct correlation was observed between chromate reductase activity and distribution of reduced chromium in culture supernatant and different cell fractions. The augmented P. putida SKG-1 isolate exhibited good efficiency towards simultaneous discoloration, dechlorination of chloroorganics and $\mathrm{Cr}^{6+}$ remediation from nutrients supplemented unsterilized diluted (1:1) tannery effluent (at natural $\mathrm{pH}$ ) under laboratory conditions. The effluent bioremediation by immobilized biomass, its regeneration, easy handling and lack of secondary sludge offer an attractive future of P. putida biomass, and can be suitably employed for eco-friendly in situ bioremediation of tannery wastewater.

\section{References}

1. O. P. Shukla, U. N. Rai, and S. Dubey, "Involvement and interaction of microbial communities in the transformation and stabilization of chromium during the composting of tannery effluent treated biomass of Vallisneria spiralis L., Bioresource Technology, vol. 100, pp. 2198-2203, 2009.

2. S. Sharma, and P. Malaviya, "Bioremediation of tannery wastewater by chromium resistant fungal isolate Fusarium chlamydosporium SPFS2-g," Current World Environment, vol. 9, pp. 721-727, 2014.

3. S. Sharma, and P. Malaviya, "Bioremediation of tannery wastewater by Aspergillus flavus SPFT2," International Journal of Current Microbiology and Applied Science, vol. 5, pp. 137-143, 2016

4. T. Srinath, T. Verma, P. W. Ramteke, and S. K. Garg, "Chromium (VI) biosorption and bioaccumulation by chromate resistant bacteria," Chemosphere, vol. 48, pp. 427-435, 2002.

5. W. H. Xu, Y. G. Liu, G. M. Zeng, X. Y. Li, H. X. Song, and Q. Q. Peng, "Characterization of Cr (VI) resistance and reduction by Pseudomonas aeruginosa," Trans Nonferrous Metal Society China, vol. 19, pp. 1336-1341, 2009.

6. R. Chandra, R. N. Bhargava, A. Kapley, and H.J. Purohit, "Bacterial diversity, organic pollutants and their metabolites in two aeration lagoons of common effluent treatment plant (CETP) during the degradation and detoxification of tannery wastewater," Bioresource Technology, vol. 102, pp. 2333-2341, 2011.

7. C. E. Paisio, M. A. Talano, P. S. Gonzalez, V. D. Busto, J. R. Talou, and E. Agostini, "Isolation and characterization of a Rhodococcus strain with phenol-degrading ability and its potential use for tannery effluent Biotreatment," Environmental Science and Pollution Research, vol. 19, pp. 3430-3439, 2012.

8. S. Sultan and S. Hasnain, "Chromium (VI) reduction by cell free extract of Ochrombactrum anthropi isolated from tannery effluent, Bulletin of Environmental Contamination and Toxicology, vol. 89, pp. 152-157, 2012.

9. S. K. Garg, M. Tripathi, and T. Srinath, "Strategies for chromium bioremediation from tannery effluent," Reviews of Environmental Contamination and Toxicology, vol. 217, pp. 75-140, 2012.

10.M. Ilias, I. M. Rafiqullah, B. C. Debnath, K. S. B. Mannan, and M. M. Hoq, "Isolation and characterization of chromium (VI)-reducing bacteria from tannery effluents," Indian Journal of Microbiology, vol. 51, pp. 76-81, 2011.

11.M. M. Bradford, "A rapid and sensitive method for the quantification of micrograms quantities of protein utilizing the principle of protein dye binding," Analytical Biochemistry, vol. 72, pp. 248-254, 1976.

12.A. Lopez, N. Lazaro, and A. M. Marques, The interface technique: A simple method of cell immobilization in gel beads, Journal of Microbiological Methods, vol. 30, pp. 231-234, 1997.

13.M. Tripathi and S. K. Garg, "Studies on selection of efficient bacterial strain simultaneously tolerant to hexavalent chromium and pentachlorophenol isolated from treated tannery effluent," Research Journal of Microbiology, vol. 5, pp. 707-716, 2010. 
14.M. Tripathi, S. Vikram, R. K. Jain, and S. K. Garg, "Isolation and growth characteristics of chromium (VI) and pentachlorophenol tolerant bacterial isolate from treated tannery effluent for its possible use in simultaneous bioremediation," Indian Journal of Microbiology, vol. 51, pp. 61-69, 2011.

15.T. Srinath, S.K. Garg, and P.W. Ramteke, Biosorption and elution of chromium from immobilized Bacillus coagulans biomass, Indian Journal of Experimental Biology, vol. 4, pp. 986-990, 2003.

16.C.P.P.A., "Technical Section Standard Method H5P," Montreal, Canada: Canadian Pulp and Paper Association. 1974.

17.M. Chowdhury, M. G. Mostafa, T.K. Biswas, and A. K. Saha, "Treatment of leather industrial effluents by filtration and coagulation process," Water Resources and Industry, vol. 3, pp. 11-22, 2013.

18.J. G. Bergmann and J. Sanik, "Determination of trace amounts of chlorine in naphtha" Analytical Chemistry, vol. 29, pp. 241-243, 1957.

19.APHA, "Standard Methods for the Examination of Water and Wastewaters," 20th ed, APHA, AWWA, WPCF, Washington DC, 1998.

20.R. Steel and J. H. Torrie, "Principles and Procedures of Statistics," McGraw Hill Book Co. Inc., New York. 1992.

21.A. Bhattacharya, A. Gupta, A. Kaur, and D. Malik, "Simultaneous bioremediation of phenol and Cr(VI) from tannery wastewater using bacterial consortium," International Journal of Applied Science and Biotechnology, vol. 3 , pp. 50-55, 2015.

22.O. O. Akpomie and B. O. Ejechi, "Bioremediation of soil contaminated with tannery effluent by combined treatment with cow dung and microorganisms isolated from tannery effluent, Journal of Bioremediation and Biodegradation, vol. 7, p. 354, 2016. doi: 10.4172/2155-6199.1000354

23.C. K. Venil, V. Mohan, P. Lakshmanaperumalsamy, and M. B. Yerima, "Optimization of chromium removal by the indigenous bacterium Bacillus spp. REP02 using the response surface methodology," ISRN Microbiology, vol. 9, 2011.

24.S. K. Garg, M. Tripathi, S. K. Singh, and A. Singh, "Pentachlorophenol dechlorination and simultaneous $\mathrm{Cr}^{6+}$ reduction by Pseudomonas putida SKG-1 MTCC (10510): characterization of PCP dechlorination products, bacterial structure and functional groups," Environmental Science and Pollution Research, vol. 20, pp. 2288-2304, 2013.

25.A. Ganguli and A.K. Tripathi, Survival and chromate reducing ability of Pseudomonas aeruginosa in industrial effluents, Letters in Applied Microbiology, vol. 28, pp. 76-80, 1999.

26.A. C. Poopal and R. S. Laxman, "Hexavalent chromate reduction by immobilized Streptomyces griseus," Biotechnology Letters, vol. 30, pp. 1005-1010, 2008.

27.A. Ganguli and A.K. Tripathi, "Bioremediation of toxic chromium from electroplating effluent by chromatereducing Pseudomonas aeruginosa A2Chr in two bioreactors," Applied Microbiology and Biotechnology, vol. 58, pp. 416-420, 2002.

28.A.G. Murugesan and S. Maheswari, "Uptake of hexavalent chromium from aqueous solution employing live, dead and immobilized bacterial biomass," Journal of Applied Science and Environmental Management, vol. 11, pp. 71$75,2007$.

29.J. F. Benazir, R. Suganthi, D. Rajvel, M. P. Pooja, and B. Mathithumilan, "Bioremediation of chromium in tannery effluent by microbial consortia,” African Journal of Biotechnology, vol. 9, pp. 3140-3143, 2010. 


\section{Appendix:}

(a)

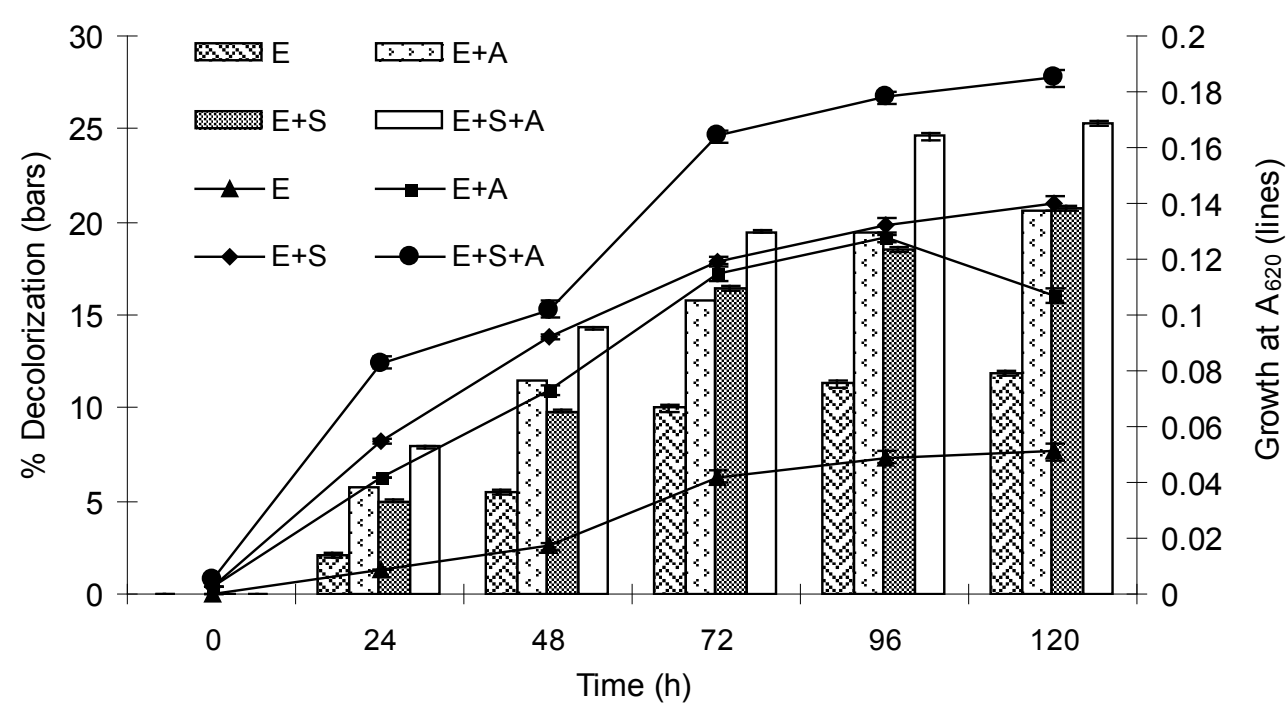

(b)

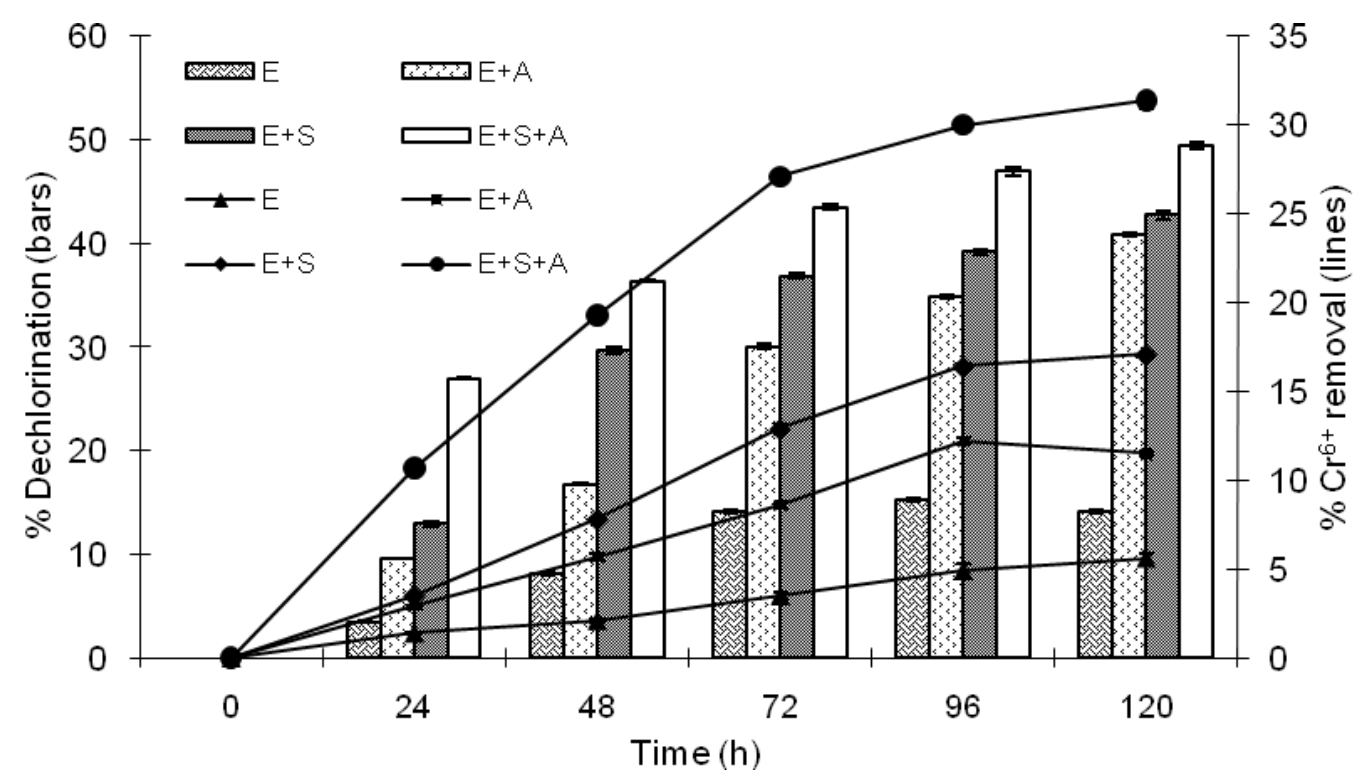

Figure 1. (a) Decolorization and bacterial growth, (b) simultaneous dechlorination and $\mathrm{Cr}^{6+}$ removal of undiluted tannery effluent with four combinations: Set-I; effluent (E) at natural pH 8.4, Set-II; effluent (E) plus augmented (A) with P. putida $(4.0 \%, \mathrm{v} / \mathrm{v})$, Set-III; effluent (E) plus nutrients (w/v, $0.5 \%$ each of glucose, peptone and yeast extract) supplemented (S), and Set-IV; effluent (E) with nutrients (as above) supplemented (S) plus augmented (A) with $P$. putida culture at $\mathrm{pH} 8.0$ (in Sets II-IV) and $30^{\circ} \mathrm{C}$ for $120 \mathrm{~h}$ under shaking $(150 \mathrm{rpm}$ ) (Error bars depict standard deviation) 
(a)

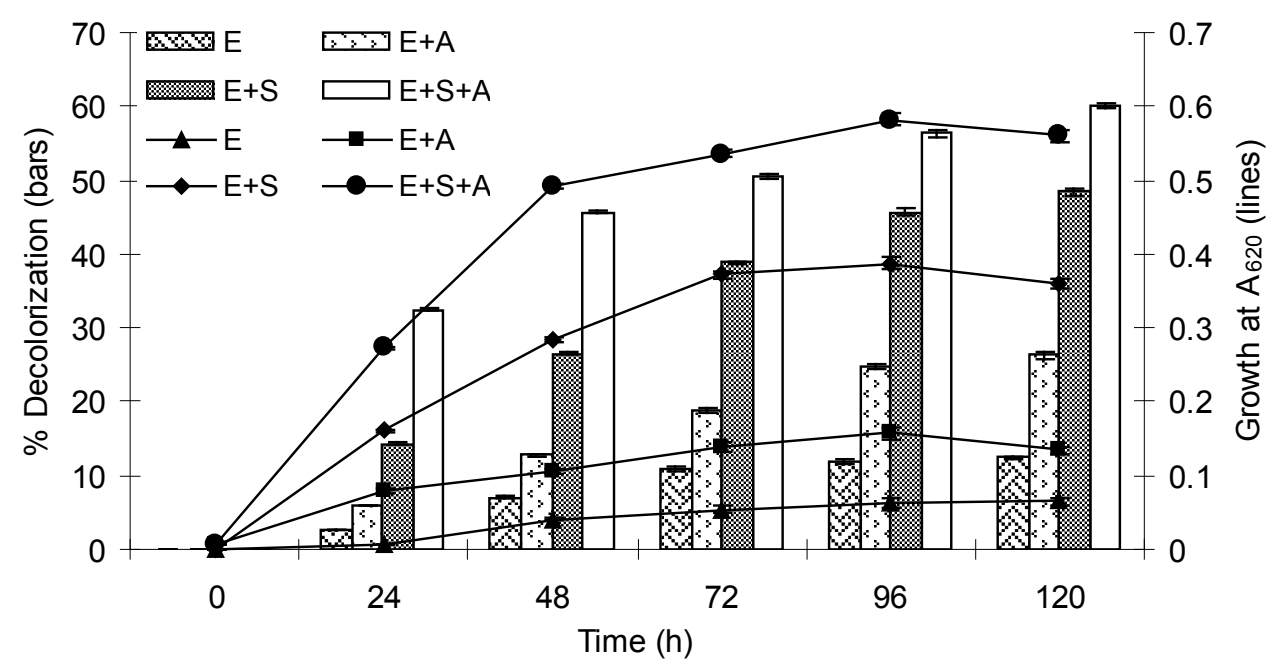

(b)

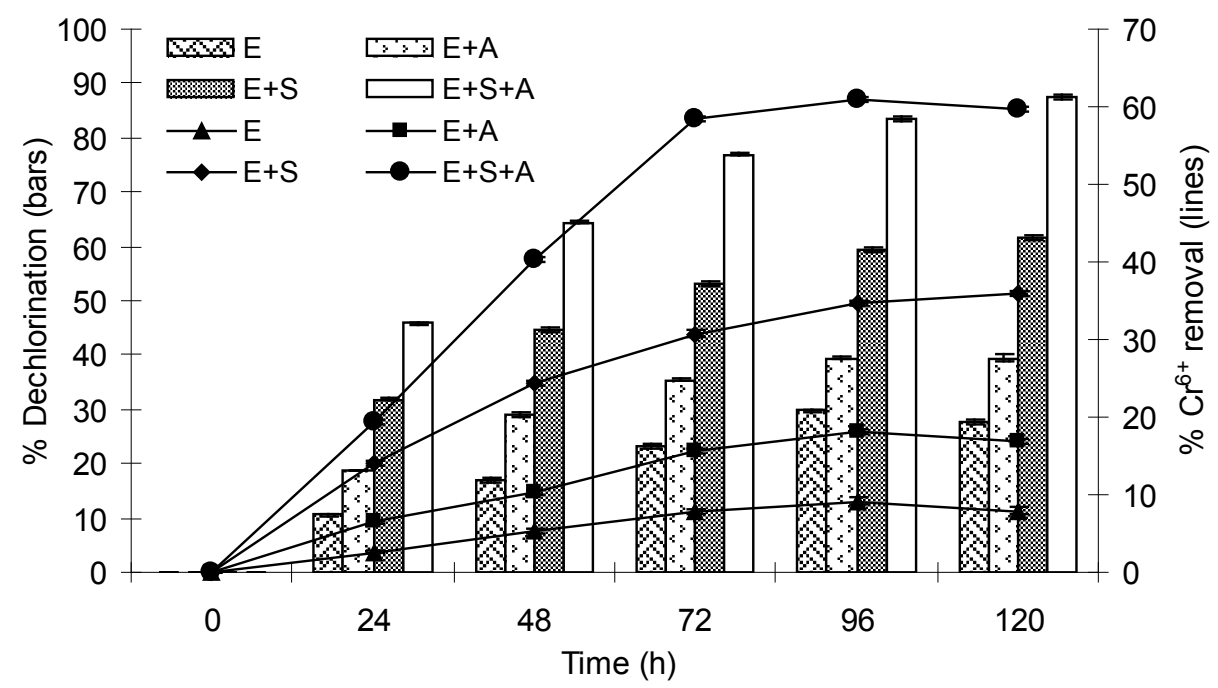

Figure 2. (a) Decolorization and bacterial growth, (b) simultaneous dechlorination and $\mathrm{Cr}^{6+}$ removal of diluted (1:1) tannery effluent with four combinations: Set-I; effluent (E), Set-II; effluent (E) plus augmented (A) with $P$. putida $(4.0 \%, \mathrm{v} / \mathrm{v})$, Set-III; effluent (E) plus nutrients (w/v, 0.5\% each of glucose, peptone and yeast extract) supplemented (S), and Set-IV; effluent (E) with nutrients (as above) supplemented (S) plus augmented (A) with $P$. putida culture at $\mathrm{pH} 8.0$ and $30^{\circ} \mathrm{C}$ for $120 \mathrm{~h}$ under shaking (150 rpm) (Error bars depict standard deviation) 
(a)

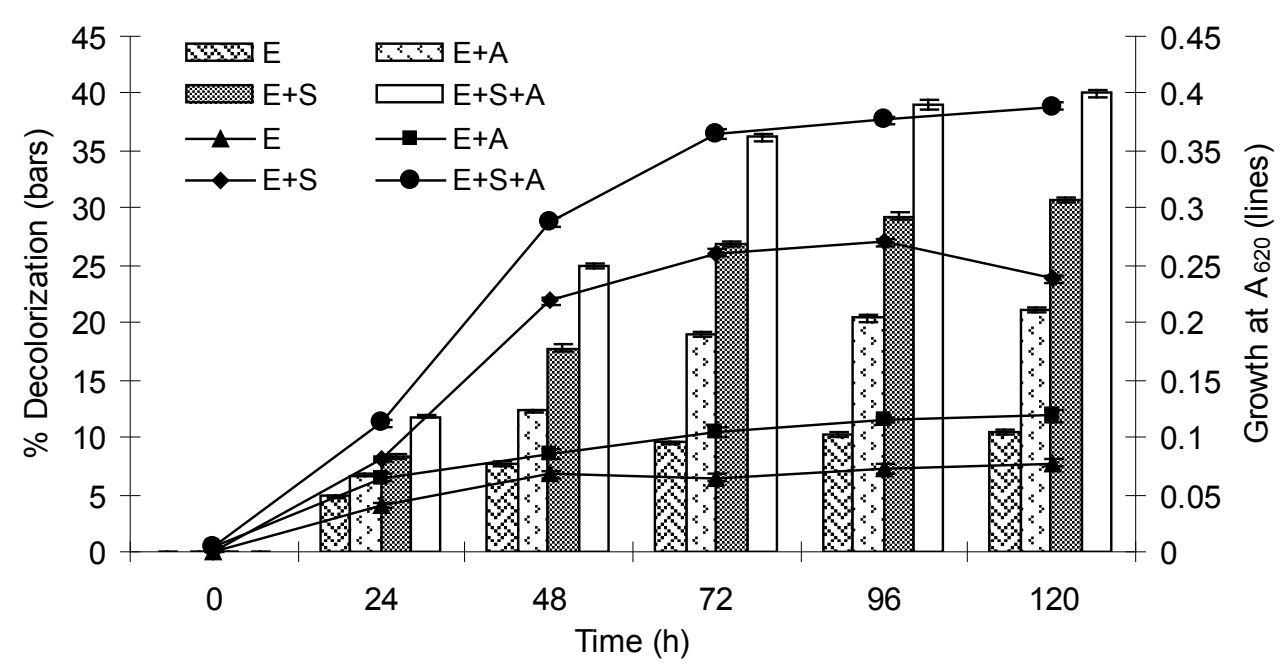

(b)

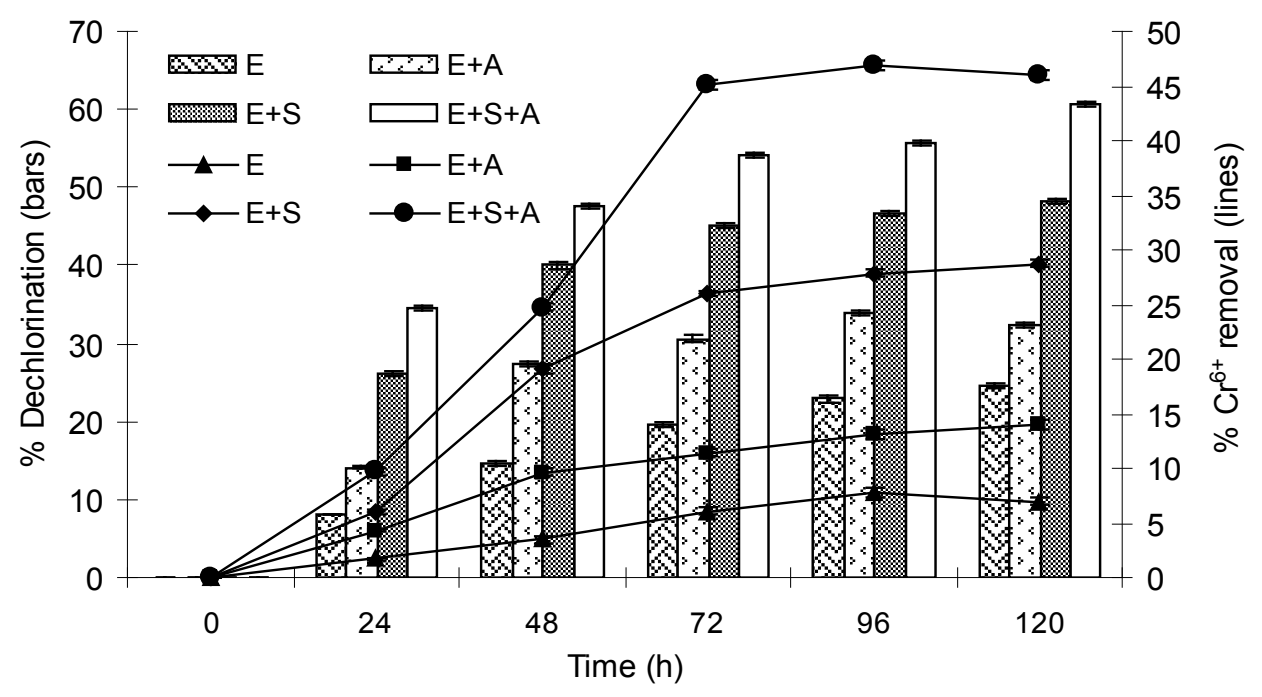

Figure 3. (a) Decolorization and bacterial growth, (b) simultaneous dechlorination and $\mathrm{Cr}^{6+}$ removal of diluted (3:1) tannery effluent with four combinations: Set-I; effluent (E) at natural pH 8.1, Set-II; effluent (E) plus augmented (A) with P. putida $(4.0 \%, \mathrm{v} / \mathrm{v})$, Set-III; effluent (E) with nutrients (w/v, $0.5 \%$ each of glucose, peptone and yeast extract) supplemented (S) plus, and Set-IV; effluent (E) with nutrients (as above) supplemented (S) plus augmented (A) with P. putida culture at $\mathrm{pH} 8.0$ and $30^{\circ} \mathrm{C}$ for $120 \mathrm{~h}$ under shaking $(150 \mathrm{rpm}$ ) (Error bars depict standard deviation) 
(a)

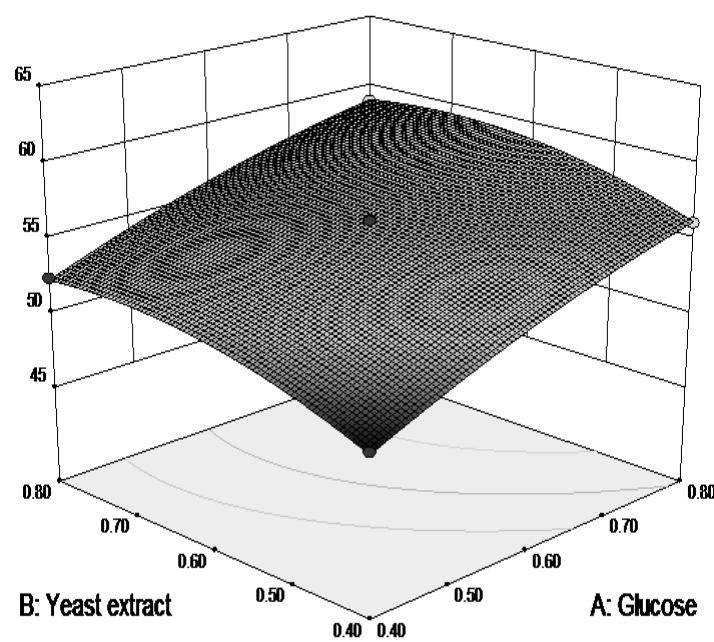

(b)

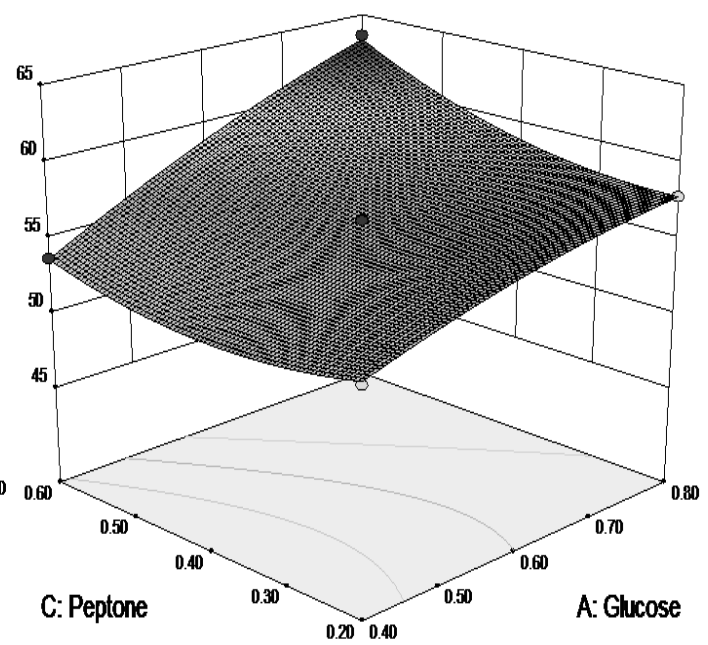

(c)

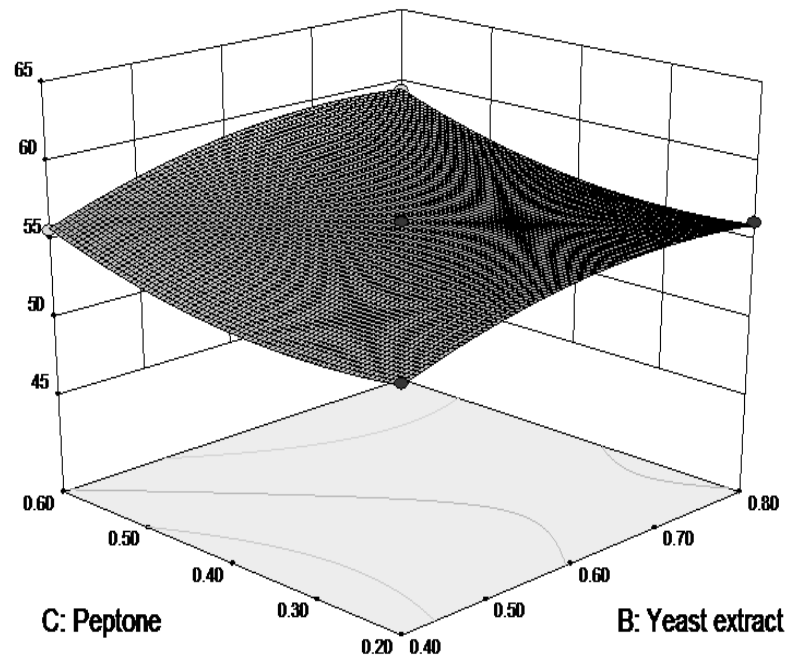

Figure 4. Response-surface curves of $\mathrm{Cr}^{6+}$ removal by P. putida isolate showing mutual interactions between (a) yeast extract and glucose, (b) peptone and glucose, (c) peptone and yeast extract. Other variables, except for two in each figure, were maintained at zero level in coded units. 
(a)

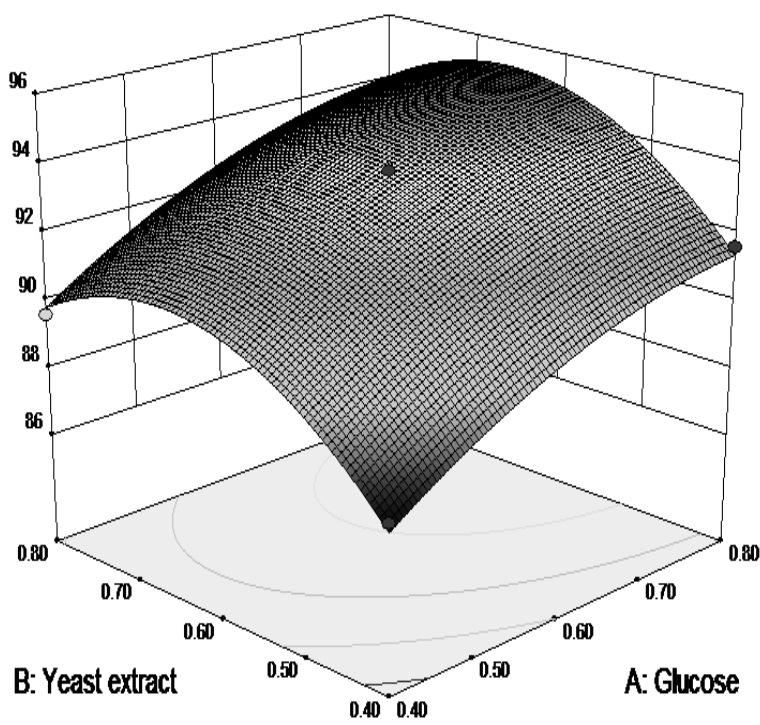

(b)

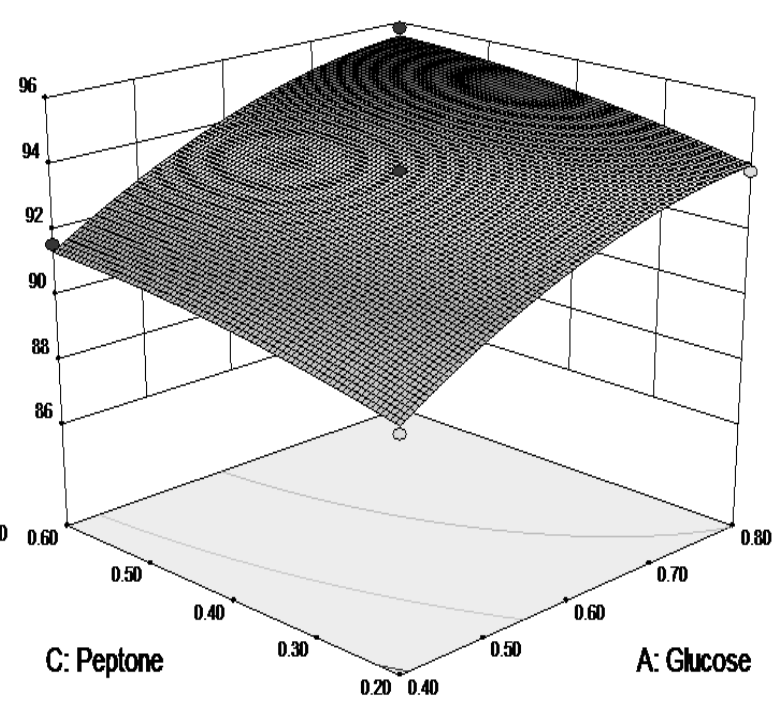

(c)

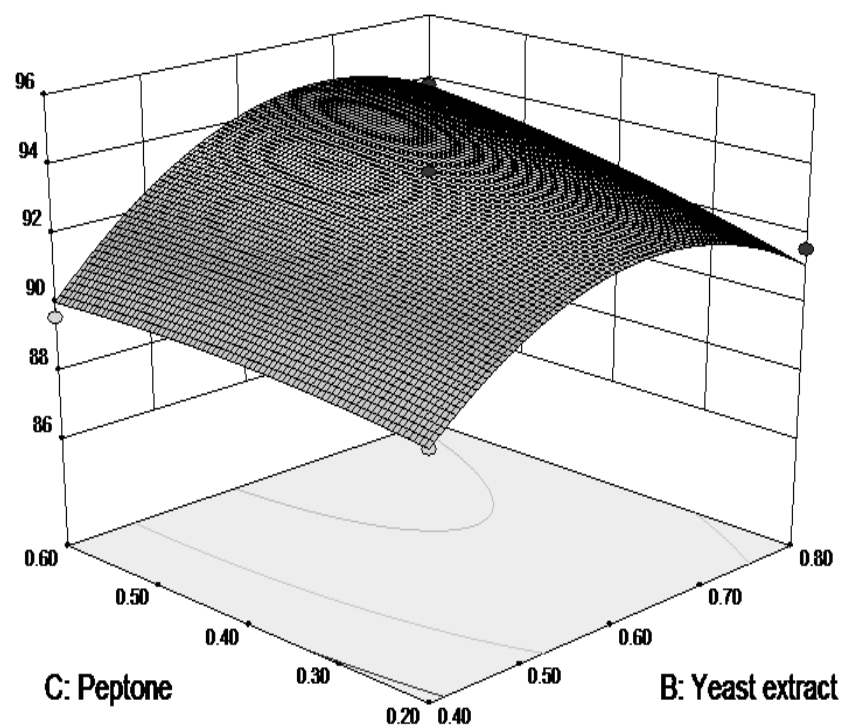

Figure 5. Response-surface curves of chloroorganics' dechlorination by $P$. putida isolate showing mutual interactions between (a) yeast extract and glucose, (b) peptone and glucose, (c) peptone and yeast extract. Other variables, except for two in each figure, were maintained at zero level in coded units 
(a)

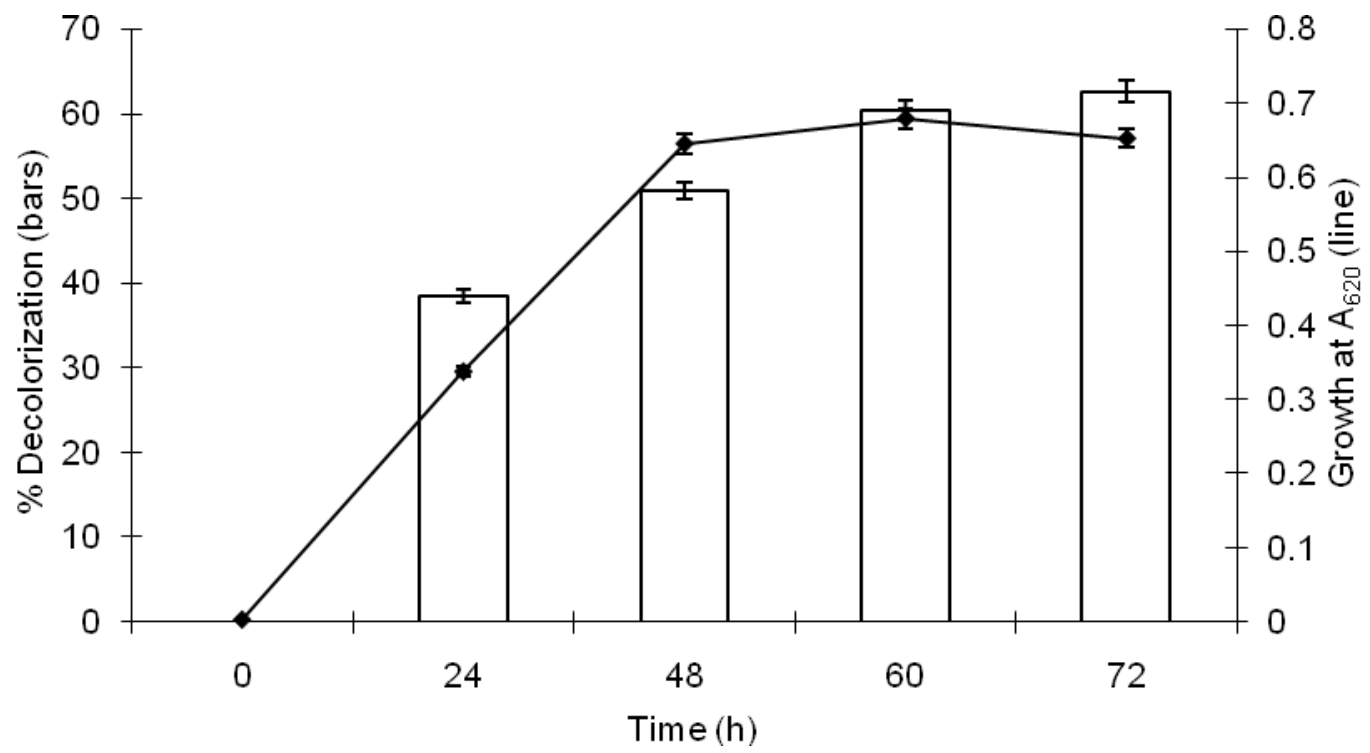

(b)

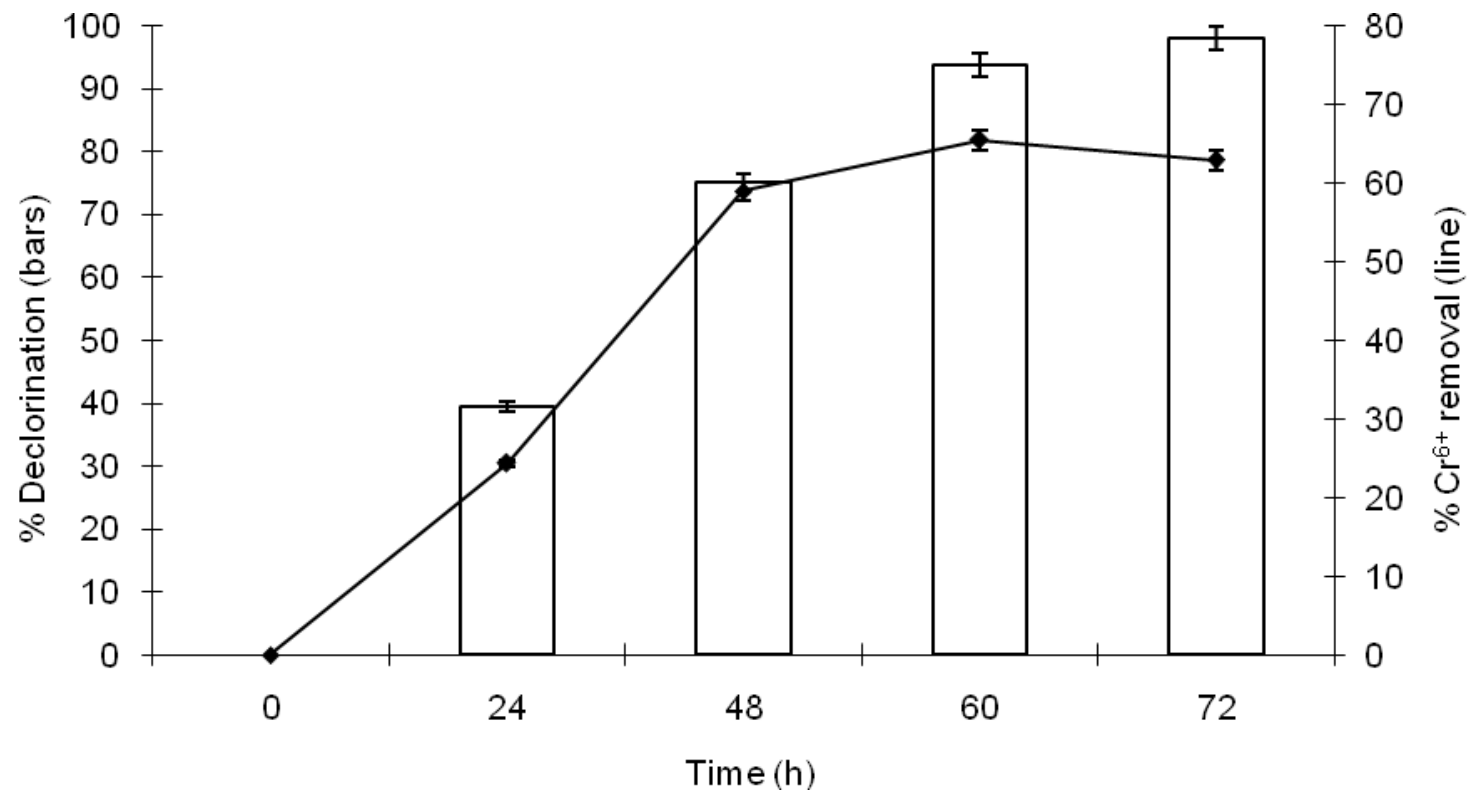

Figure 6. Bioreactor trial for (a) decolorization and bacterial growth, (b) simultaneous dechlorination and $\mathrm{Cr}^{6+}$ removal of diluted (1:1) tannery effluent supplemented with optimized nutrients (w/v, $0.8 \%$ glucose, $0.6 \%$ peptone and $0.6 \%$ yeast extract), augmented with optimized P. putida $(4.0 \%, \mathrm{v} / \mathrm{v})$ culture and incubated at $30^{\circ} \mathrm{C}$ for $72 \mathrm{~h}$ under aeration $(0.4 \mathrm{vvm})$ and agitation $(125 \mathrm{rpm})$ conditions(Error bars depict standard deviation) 